\title{
INTERNATIONAL SOCIETY FOR EIGHTEENTH-CENTURY STUDIES EAST-WEST SEMINAR 1995
}

The International Society for Eighteenth-Century Studies (ISECS) invites applications from younger scholars in all fields of eighteenth-century studies to attend an East-West seminar in Münster, Germany, in July 1995, on the eve of the International Congress on the Enlightenment in Münster.

The seminar is intended to promote intellectual exchange and to establish personal contacts between scholars from East European countries and the West. All expenses, including travel and lodging, will be paid.

To be eligible, candidates must satisfy the following requirements :

1. They must be less than forty years old on 1st January 1995.

2. They must have a $\mathrm{PhD}$ or its equivalent.

3. They must be able to speak French or English, preferably both.

4. If accepted, they must write an original paper, in English or French, of about 20 typewritten pages on the theme of the seminar, and they must submit it by lst June 1995 so that it can be circulated in advance.

The theme of the seminar for 1995 will be :

\section{Intellectuals, Men and Women of Letters.}

The intellectual as a social type emerged in the eighteenth century. As a writer, thinker, artist, and adviser of monarchs, he or she often set the tone of cultural and political life. Papers from any discipline on any aspect of this theme will be welcome.

Applications should be sent to ISECS, Voltaire Foundation, 99 Banbury Road, Oxford OX2 6JX, England by 1st December 1994. They should include :

1. Nationality;

2. Date of birth;

3. A short curriculum vitae with date of $\mathrm{PhD}$ and list of principal publications (not book reviews, unpublished papers and lectures);

4. A brief description of the proposed paper, 250-500 words;

5. Two letters of recommendation, which can be sent separately or be forwarded with the application by the recommenders;

6. Full information on training in foreign languages.

Scholars from Central and Eastern Europe will be given a month's fellowship, from 18th July to 18th August, which will leave them free to attend the Enlightenment Congress and to pursue their work in any way they like after the seminar sessions, which will take place from July 18 to 22 . Scholars from the West will receive a one-week fellowship to attend that meeting. The discussions will take place in English and French, and the fellows will be housed in or near Münster.

Revue de synthèse : IV S. Nos 1-2, janv.-juin 1994. 